Tjalling C. Koopmans Research Institute

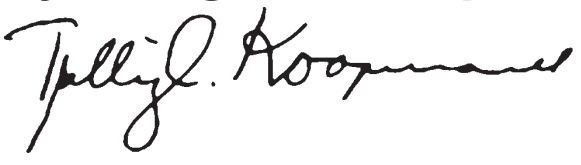

Discussion Paper Series nr: 12-04

\title{
The Effects of Internationalization on Innovation: Firm-Level Evidence for Transition Economies
}

Martijn Adriaan Boermans

Hein Roelfsema 


\section{Tjalling C. Koopmans Research Institute Utrecht School of Economics \\ Utrecht University}

Kriekenpitplein 21-22

3584 EC Utrecht

The Netherlands

telephone +31302539800

fax +31302537373

website www.koopmansinstitute.uu.nl

The Tjalling C. Koopmans Institute is the research institute and research school of Utrecht School of Economics.

It was founded in 2003, and named after Professor Tjalling C. Koopmans, Dutch-born Nobel Prize laureate in economics of 1975.

In the discussion papers series the Koopmans Institute publishes results of ongoing research for early dissemination of research results, and to enhance discussion with colleagues.

Please send any comments and suggestions on the Koopmans institute, or this series to J.M.vanDort@uu.nl

ontwerp voorblad: WRIK Utrecht

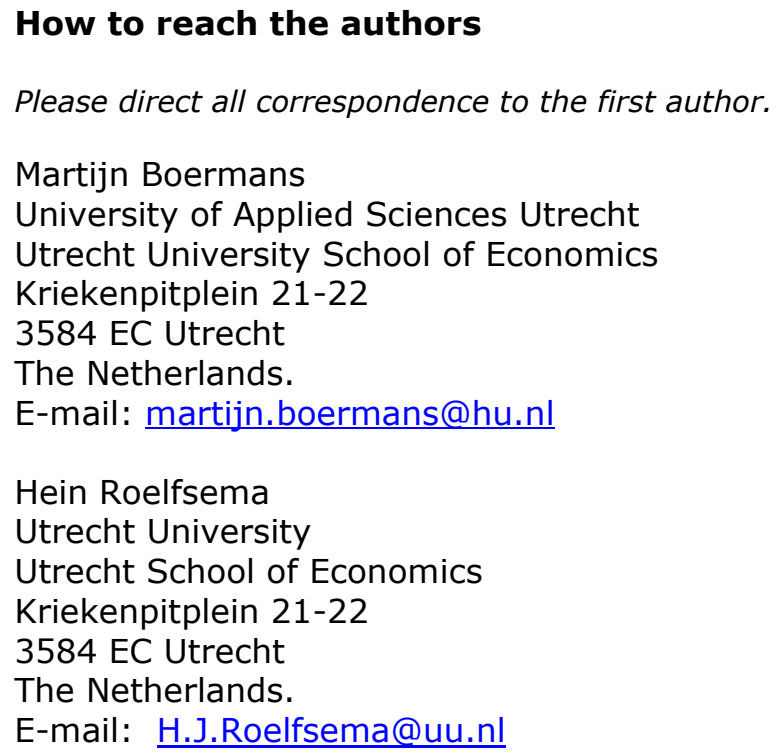


Utrecht School of Economics

Tjalling C. Koopmans Research Institute

Discussion Paper Series 12-04

\title{
The Effects of Internationalization on Innovation: Firm-Level Evidence for Transition Economies
}

\author{
Martijn Adriaan Boermans ${ }^{a, b}$ \\ Hein Roelfsema ${ }^{a}$ \\ ${ }^{a}$ Utrecht School of Economics \\ Utrecht University \\ ${ }^{\mathrm{b}} \mathrm{HU}$ University of Applied Sciences Utrecht
}

March 2012

\begin{abstract}
It is well-documented that international enterprises are more productive. Only few studies have explored the effect of internationalization on productivity and innovation at the firm-level. Using propensity score matching we analyze the causal effects of internationalization on innovation in 10 transition economies. We distinguish between three types of internationalization: exporting, FDI, and international outsourcing. We find that internationalization causes higher levels of innovation. More specifically, we show that (i) exporting results in more R\&D, higher sales from product innovation, and an increase in the number of international patents (ii) outward FDI increases R\&D and international patents (iii) international outsourcing leads to higher sales from product innovation. The paper provides empirical support to the theoretical literature on heterogeneous firms in international trade that argues that middle income countries gain from trade liberalization through increases in firm productivity and innovative capabilities.
\end{abstract}

Keywords: Firm heterogeneity, Internationalization, Innovation, Transition economies

JEL classification: D22, F14, F23, 012

\section{Acknowledgements}

We thank participants at the $73^{\text {th }}$ International Atlantic Economic Society (IAES) Conference in Turkey and the international conference on "Entrepreneurship, Family Firms and Economic Development" in Poland, Cracow University of Economics, Università Politecnica delle Marche, the European Council for Small Business and Entrepreneurship (ECSB) and the International Council for Small Business (ICSB) the for valuable comments and the European Bank for Reconstruction and Development (EBRD) for assistance with the data. 


\section{INTRODUCTION}

A burgeoning literature on firm heterogeneity provides as a stylized fact that only the most productive firms within an industry enter foreign markets (Melitz, 2003). By contrast, more recent papers stress that firms can influence productivity levels through export participation (Melitz and Constantini, 2008). Instead of treating the productivity draw as exogenous, these studies highlight the importance of within firm decision-making in which managers anticipate the gains from exporting by choosing to upgrade technologies so as to improve the productivity of the firm. Further, internationalization allows firms to take advantage of technological spillovers and organizational learning.

Recently, for individual middle-income countries several empirical studies demonstrate that firms that internationalize learn and improve productivity (De Loecker, 2007; Aw et al., 2008, 2011; Damijan et al., 2009). We contribute to this agenda by studying the impact of various internationalization modes on innovation using a broader dataset that consists of firms from 10 transition countries. In these transition economies, at the firm-level organizational behavior is shaped by the rapid transformation of society (Meyer and Peng, 2005; Berglöf et al., 2010). However, firms have reacted differently to the opening-up of the economy. After major reform and economic development, some firms have been unable to take advantage of the transition to a market-oriented economy due to the planned economy legacy that still affects organizational norms and practices (Gelbuda et al., 2008; Estrin et al., 2009). We use the variation in response to institutional change in order to isolate the causal effects of internationalization on firm productivity and innovation.

To analyze the impact of internationalization one must take into account that firms with high productivity and low communist legacy self-select into exporting and FDI (Helpman et al., 2004; Filatotchev et al., 2008). To account for self-selection, we use propensity score matching techniques which allow for the comparison of domestic and internationally active firms. Based on data of 1.355 firms, the estimates show that international activities enhance R\&D efforts, product innovation, and international patenting. These impacts are most pronounced for exporting compared to other forms of internationalization. Hence, the paper provides support for the view that stresses the importance of the gains from trade liberalization at the micro-level for firms from middle income countries that come about through productivity improvements and stronger innovative capabilities. 
Section 2 provides related literature on firm heterogeneity, trade and innovation. It also identifies several important features of the transition context. Section 3 explains the principles behind propensity score matching and describes the data. Section 4 gives the main results. Section 5 concludes with a discussion of the effects of internationalization on innovation in transition economies. As is common for research using propensity score matching, an extended Appendix gives in-depth information on the methods deployed in this study and discusses the properties of the matching procedure in detail.

\section{RELATED LITERATURE}

\subsection{International trade and firm heterogeneity}

The seminal Melitz' (2003) model has revolutionized theoretical developments in the field of international trade. At its core is the observation that exporters within an industry are the most productive firms, an assumption founded on early empirical work in the late 1990s (Bernard and Jensen, 1999; Clerides et al., 1998; Roberts and Tybout, 1997). Melitz (2003) focuses on the effects of trade liberalization; however, the clever treatment of firm heterogeneity in the model's set-up has inspired a growing literature that focuses on the interaction between productivity and internationalization strategies. ${ }^{1}$ These studies start from Melitz' assumption that productivity differences are exogenously given to the individual firm by a draw from a known productivity distribution. Therefore, individual firm productivity levels are revealed (or have already materialized) to the firm's management before the internationalization decision is taken. Only the most productive firms are internationally active and can overcome the sunk costs associated with foreign market entry and exploitation. This assumption is important, because in a steady state the framework implies that the causality runs from productivity to international activities, for which several econometric studies for developed economies provide supporting evidence (Bernard and Jensen, 2004; Bernard et al., 2011; Wagner, 2007, 2011).

However, the initial convenient modelling assumption of the exogenous productivity draw has more recently inspired several authors to investigate modifications where firm management can influence productivity. Although he does not use the Melitz' model itself, Yeaple (2005) studies a situation where a set of homogenous firms can make investments

\footnotetext{
${ }^{1}$ By now, there are many extended versions of the Melitz' (2003) workhorse model which include inter alia endogenous mark-ups and pro-competition effects (Melitz and Ottaviano, 2008; Impullitti and Licandro, 2010 ), multi-product firms (e.g. Mayer et al., 2011), multiple export destinations (Arkolakis, 2011), and, selection within firms (Bernard et al., 2011). For a brief introduction on the development of "new new trade theory" see the "Trade in a Globalizing World" (WTO, 2008). For an overview of empirical work in this field, see Bernard et al. (2011).
} 
to increase productivity, which in turn affect the internationalization choice. The backward induction strategy in this paper opens-up to reverse causality, as productivity is influenced by the expectation that investment in skills and R\&D will increase the firms profit through (a higher probability of) success in foreign markets. Melitz and Constantini (2008) present a model in which firms anticipate trade liberalization by making investments to upgrade the production process through innovation. The reason is that higher expected profits from internationalization are contingent on higher productivity. Using the same logic, Bustos (2011) shows that especially firms with medium productivity levels have an interest in investing in productivity, since these firms are at the fringe and are most probably hit by the selection processes following trade liberalization. ${ }^{2}$

From the early empirical literature on trade and heterogeneous firms arises the stylized fact that productivity causes firms to internationalize. However, nearly all these studies concentrate on developed economies for which it is less likely that the causality runs the other way around (Damijan et al., 2009; Wagner, 2011). The reason is that innovation and productivity growth in these countries are already connected to a comparative advantage in knowledge intensive production. Hence, firms that are engaged in international trade do so because they already possess competitive advantages in knowledge intensive production processes and have adopted world-class technologies to compete abroad. The first-order effect of trade liberalization therefore is to reallocate resources towards the most productive (knowledge intensive) firms as predicted by the Melitz' model, and not so much making existing firms more productive. ${ }^{3}$

To investigate potential spill-back effects of internationalization of the firm on productivity, several authors have turned to developing and middle-income countries. It is expected that firms in these regions use their trade contacts with developed countries to upgrade technology through the imports of knowledge intensive capital goods and learn from their partner's business practices and capabilities. At the macro level, knowledge spillovers from trade are at the core of many endogenous growth models, however, only recently these mechanisms have been incorporated into papers that study the effects of exports on productivity at the micro level.

\footnotetext{
2 Whereas these studies focus on how trade influences production decision within the firm, others stress that in imperfect information settings exporting firms learn about the condition in foreign markets, which reveals their competitive advantages, so as to provide stronger or weaker incentives for deeper foreign commitments. For example, this can result in sequential exporting, in which there are relatively few firms with wide market scope and deep penetration (Albornoz-Crespo et al., 2010; Arkolakis, 2010; Arkolakis and Muendler, 2010; Eaton et al., 2008).

${ }^{3}$ Exceptions are Balwin and Gu (2007) and Wagner (2002) who find positive effects of exporting on labor productivity for Canada and Germany respectively.
} 
The primary focus of these studies is to show the (beneficial) effects of trade liberalization for middle income countries, and find that more trade results in quality upgrading and product differentiation within the firm. ${ }^{4}$ In a study using plant-level panel data from Chilean manufacturers Pavcnik (2002) estimates the changes in productivity over a period of massive trade liberalization. She finds within plant productivity gains in sectors that face most import competition, which can be attributed to trade liberalization. More recent work also exploits the regime shift of rapid trade liberalization. Using Canadian plant-level data, Lileeva and Trefler (2010) show that trade liberalization induces firms to invest in product innovation. Goldberg et al. (2010) use firm-level data from India to find that trade liberalization induces domestic firms to use newly available foreign inputs. Bustos (2011) studies the effect of trade liberalization on R\&D efforts of Argentinean firms. She shows that firms in sectors where reductions in tariffs are pushed furthest exert the highest growth in R\&D. Hence, international trade opportunities result in a different allocation of the firm's resources in equilibrium and boost innovation.

In contrast to the clever use of trade interventions, other papers look at firm-level productivity trajectories before and after entry into foreign markets (see for a review Bernard et al., 2011). For Taiwan, Aw et al. (2007) show that productivity gains from exporting are higher when firms also invest in $R \& D$ and train workers to facilitate technological transfers. Furthermore, Aw et al. (2008) allow for feedback effects from exporting on productivity to demonstrate that exporters are more inclined to make complementary firm-level investments in productivity enhancing activities. Castellani and Zanfei (2007) explore the effects of exporting and FDI on productivity and innovation using data from 785 large Italian manufacturers. They find that cross-boarder activities are associated with higher productivity given the level of innovation. Criscuolo et al. (2010) use Community Innovation Survey (CIS) data for the United Kingdom and focus on multinational firms. They find that firms that are active abroad generate more innovation outputs, but also use more inputs for knowledge production. Bloom et al. (2011) find that increased competition from Chinese imports induces selection effects among European firms where the most productive surviving firms tend to innovate more in terms of R\&D, patenting and upgrading IT technologies. For individual EU countries, several studies rely on data from Spanish manufacturers to analyse the relationship between internationalization and innovation. Salomon and Jin (2010) find that exporting raises productivity regardless of the

\footnotetext{
${ }^{4}$ Verhoogen (2008) shows that during the Mexican peso-crisis exporting firms raise product quality more compared to domestic firms. Baldwin and Robert-Nicoud (2008) also demonstrate that trade liberalization creates selection effects which affects innovation, however, whether this effect of trade-induced innovation will be positive depends on the type of international knowledge spillovers.
} 
level of innovative capacity. Kafouros et al. (2008) show that internationalization increases the firm's capacity to raise productivity through innovation, while Monreal-Pérez et al. (forthcoming) find no additional learning effects from exporting on product or process innovation. Garciá et al. (forthcoming) show that exporting increases productivity and that the size of the gains is larger for more innovative firms which is suggestive for greater absorptive capacity for knowledge transfers from foreign market participation.

For developing countries, Amiti and Konings (2007) use a tariff reform shock in Indonesia to uncover that firms who start importing increase productivity levels through learning, increased product variety and improved quality. Blalock and Gertler (2004) also analyse firm-level data from Indonesia and show that exporters increase productivity faster than non-exporters. Kasahara and Rodrigue (2008) find that Chilean manufacturers that import foreign inputs become more productive. Van Bieseboeck (2005) uses microdata from several African countries and presents evidence that exporting results in higher labor productivity, especially when firms trade with more developed economies. Concluding, studies that concentrate on middle income and developing countries show far more evidence in favour of the hypothesis that internationalization results in higher productivity and innovation.

\subsection{Evidence from matched firms}

A few studies have applied matching methods to disentangle the impacts of internationalization using firm-data from a single developed country. ${ }^{5}$ In this field, among the first studies to employ these techniques is Wagner (2002). He uses pooled data from Eastern German manufacturers and examines the effect of 182 export starters in the period before reunification of East and West. In his letter he explains how matching exporting firms to a constructed control group can yield insights on the effect of exporting. To account for self-selection into export participation, Wagner (2002) uses firms size, value added and wage levels. From the analysis he concludes that firm that start exporting grow faster but there is no effect of exporting on labor productivity.

Arnold and Hussinger (2005) use CIS data to match German exporters and non-exporters on total factor productivity, size, R\&D expenditure, new product development, and wages levels, but find no gains in productivity from exporting. In related work, Girma et al. (2004) use a difference-in-difference approach based on propensity score matching on size,

\footnotetext{
${ }^{5}$ In contrast to our methodology (see Section 3), these studies take advantage of the time-dimension in the large panel datasets, which means they are able to match on the basis of lagged firm characteristics.
} 
ownership and wage levels to account for selection into exporting of British firms. They find that starting to export improves productivity growth, but these effects are rather short-lived and disappear one year after internationalization. Navaretti and Castellani (2004) apply a similar matching estimator for Italian firms that invest in foreign establishments for the first time. They find that FDI increases productivity and output growth. Damijan and Kostevc (2010) analyze the sequencing between exporting and innovation. Using firm-level data from Spanish manufacturers they apply propensity score matching techniques and pair firsttime exporters and first-time innovators to non-exporters and non-innovators based on value added, capital, size, foreign ownership and sector dummies. The results show that importing precedes innovation, but such sequencing between exporting and innovation is less strong although still important for small and medium sized firms. Firms higher on the technology ladder benefit more from trade participation than technologically laggard firms.

Our paper is also close to De Loecker (2007) who uses matching methods to study the effects of internationalization in a transition economy, Slovenia. Clearly, small Slovenia may be considered an interesting special case, as it is the most developed and open part of the former Yugoslav Republic next to Austria and the North of Italy. De Loecker (2007) shows that when accounting for selection effects exporting results in higher levels of productivity growth. In a recent study, Hagemejer and Tyrowicz (2012) use propensity score matching to evaluate the impact of foreign ownership on the performance of Polish firms. They find that inward FDI improves productivity, but note that foreign investors prefer and choose to invest in Polish firms that are exporting. Overall, these studies based on matching methods find some learning-by-exporting effects but do not provide a consistent picture.

\subsection{Context specific studies}

Over the past twenty years, many countries from Central and Eastern Europe (CEE), the Commonwealth of Independent States (CIS) and Central Asia have experienced a turbulent period marked by a transition towards a market economy. One central feature of this transformation has been the opening-up of the domestic markets to foreign trade and investment (Marinov and Marinova, 2011). ${ }^{6}$ For instance, in the early 1990s privatization of state-owned firms was widely regarded as a milestone in the transition, because private ownership combined with market forces would ensure efficient allocation of resources and economic performance. Djankov and Murrell (2002) and Estrin et al. (2009) evaluate prior

\footnotetext{
${ }^{6}$ The broad systematic changes in transition economies entail two types of reforms (Svejnar, 2002). The first type includes price liberalization, the dismantling of the communistic system and rapidly opening-up of the economy to international trade. The second type involve building law, regulations and institutions that ensure the functioning of a market economy based on well-defined property rights, enforcement of contracts and limited corruption.
} 
literature on the effects of privatizations in transition economies. In general, most empirical firm-level studies find that privatizations to foreign owners significantly improve firm productivity and related measures of firm performance (see Hagemejer and Tyrowicz, 2012). In a broader context, these results reflect the limited skills, management practices, corporate governance and access to capital and foreign markets of local managers. During the restructuring period, foreign investors provide knowledge and invest in training local managers. In addition, reorganization efforts increase the demand for managerial capabilities to run a firm in a more competitive environment (Newman, 2000; Filatotchev et al., 2003; Kriauciunas and Kale, 2006).

There is evidence that the contacts with foreign partners and the influx of capital are associated with organizational learning. In their celebrated work, Lyles and Salk (1996) study the role of knowledge acquisition in Hungarian international joint ventures at the onset of the transition phase. This study highlights the central role of top managers in the process of organizational restructuring and how absorptive capacity and ties with foreign partners affect knowledge transfers. Using foreign inputs, domestic firms can quickly unlearn old organizational routines and thus be liberated from the legacy of the communist system (Newman, 2000). In this process of overcoming the administrative heritage based on central planning, contextual factors play a critical role for firms to build dynamic capabilities and organizational routines to meet demands of a market-oriented economy (see Kriauciunas and Kale, 2006; Steensma et al., 2008; Dixon et al., 2010).

Following the wave of privatization efforts and institutional transformations there is still a legacy in terms of administrative heritage form the former Soviet period which affects organizational routines and the management of the firm (Gelbuda et al., 2008; Estrin et al., 2009). Signs of inertia and slow adaptation to organizational excellence are evident in Bloom and Van Reenen (2010). In a cross-country comparison they find relatively low scores on management and organizational practices in transition economies. Bloom et al. (2011) show that this gap is especially large in Central Asian transition economies that have relatively low levels of competition, foreign investment and human capital. Ultimately, increasing market reforms and trade liberalization can foster competition, foreign investment and put pressure on education to install better management.

There is a small set of studies that investigates the drivers of internationalization in transition economies at the firm-level. Rojec et al. (2004) show that Estonian and Slovenian manufacturers which are owned by foreigners are more efficient, and that ownership in turn affects the propensity to export. Using a sample of 406 firms from Estonia, Hungary, 
Poland, Slovakia and Slovenia, Filatotchev et al. (2008) find that foreign investment and control of the firm has a positive effect on export intensity. Further, greater foreign control over the strategic management of the firm increases exporting. Work by Wagner (2002) looks at export-starters from Eastern Germany before the reunification of East and West and finds some indication that exporting increases firm performance. By using CIS data, Damijan et al. (2010) show that exporting results in higher levels of R\&D spending. Work by Hagemejer and Kolasa (2011) builds on data from Polish firms and distinguishes three internationalization modes. They find that exporting as well as firms with foreign affiliates are more productive than domestically oriented firms. Our paper is close to Damijan et al. (2009). They study how trade and FDI inflows affect learning and productivity improvements in six transition economies. Using a Heckman selection model, they find that in Slovenia and Romania, exporting to advanced markets gives rise to greater learning than with trade to less developed economies. Inflows of foreign capital allows for firms to learn in Bosnia-Herzegovina, Croatia, Romania and Serbia, but this positive effect of FDI on productivity is insignificant in Bulgaria and Macedonia.

\section{METHODOLOGY}

A common problem in the international trade literature that deals with firm heterogeneity is that there is an obvious selection effect into exporting. The early papers clearly show that internationally active firms are more productive, however, does productivity cause firms to be international (Bernard and Jensen, 1999; Clerides et al., 1998)? To isolate the causal effects of productivity differences on internationalization, most authors use a conditional logit procedure that correlates the differences in exports and productivity across firms conditioning on the factors that drive the firm towards international activities (Castellani and Zanfei, 2007). As discussed in the related literature section, a stylized fact is that indeed productivity differences increase degree of internationalization of the firm (Bernard et al., 2011).

The selection of more productive firms into exporting causes major problems for studies that try to uncover the causal effects of internationalization on firm performance. This emerging literature deals with selection effects in two ways. A first strategy is to cleverly pick events that generate variance in both internationalization and the variable of interest (productivity, innovation), for example because of a new regional trade liberalization agreement. Then these papers over time observe the changes in the path of the variables of 
interest (Pavcnik, 2002; Verhoogen, 2008; Goldberg et al., 2010; Lileeva and Trefler, 2010; Bustos, 2011).

However, firm-level data collection often involves survey methods for which it is difficult to trace individual firms over time and as such warrant panel analysis. The data from transition economies is a cross-section of firms, which means we cannot observe the firm-level adjustments over time. To overcome possible selection biases, a second set of papers uses matching techniques to extract causal effect of internationalization. How does this matching method work? Suppose that in a cross section setting we ask whether internationally active firms are more innovative. In order to obtain a credible estimate of the effect of internationalization for the firm, we must asses these effects in contrast to those in a counterfactual. The crucial problem arises when such counterfactuals cannot be found in the data because of selection effects (Wagner, 2002; Girma et al., 2004). In our case, we look for two types of counterfactuals. For internationally active firms, we have to compare the outcomes to firms that are of 'the same type' but are not internationally active. By contrast for internationally inactive firms we have to compare them to firms with the same characteristics that do engage in international trade in terms of, say, productivity. But then if all high productivity firms export and all low productivity firms do not export, we cannot find such counterfactuals in the cross sectional data from which we can infer the (unbiased) effects of internationalization on innovation.

To control for selection we want to match 'the same types', but what if selection reduces the number of counterfactuals from the dataset to such an extent that there too few pair-wise observations? Rosenbaum and Rubin (1983) have provided a way out of this problem by introducing the propensity score, as being the probability that a firm is, in our case, internationally active. By using the 'estimated but not actual' internationalizers as counterfactuals to internationally active firms we can infer a causal effect of internationalization for internationally active firms. In addition, by using the estimated non internationally active firms who are in fact internationally active as control for non internationally active firms as counterfactuals we find the causal effect of internationalization on firms that are presently not internationally active (for more details, see Appendix 3).

We use data from EBRD-World Bank Management, Organisation and Innovation (MOI) survey. The survey was implemented based on face-to-face interviews with two top managers in transition economies during the period from October 2008 to March 2009. The interviews took on average 50 minutes. The response rate was 44 percent. 
The survey is designed around questions related innovation, and includes various measures for R\&D, product innovation and patents. Also, this survey also gives information about internationalization of firms. More specific, the data provide information on export, FDI and outsourcing, which allows us to link internationalization modes to innovative activities at the firm-level. In total, 1.355 firms are included in a sample from 10 transition economies. Table 1 gives summary statistics and correlations between the variables of interest; for the sake of brevity, the operationalization of the variables is in Appendix 1.

Table 1: summary statistics and correlations

\begin{tabular}{|c|c|c|c|c|c|c|c|c|c|}
\hline & & mean & s.d. & 1 & 2 & 3 & 4 & 5 & 6 \\
\hline & Internationalization & & & & & & & & \\
\hline 1 & EXPORT & 0.23 & 0.42 & & & & & & \\
\hline 2 & $F D I$ & 0.07 & 0.25 & 0.09 & & & & & \\
\hline \multirow[t]{2}{*}{3} & OUTSOURCE & 0.09 & 0.29 & 0.13 & 0.18 & & & & \\
\hline & Innovation & & & & & & & & \\
\hline 4 & $R \& D$ & 0.38 & 0.49 & 0.04 & 0.10 & 0.10 & & & \\
\hline 5 & PROD_INNOV & 19.33 & 25.05 & 0.06 & 0.04 & 0.10 & 0.27 & & \\
\hline \multirow[t]{2}{*}{6} & PATENT & 0.08 & 0.27 & 0.16 & 0.22 & 0.11 & 0.14 & 0.07 & \\
\hline & Controls & & & & & & & & \\
\hline 7 & $S I Z E$ & 5.04 & 0.92 & 0.12 & 0.11 & 0.06 & 0.20 & 0.09 & 0.16 \\
\hline 8 & UNIQUENESS & 2.94 & 1.17 & 0.19 & 0.02 & 0.07 & 0.10 & 0.10 & 0.09 \\
\hline 9 & FOREIGNOWN & 0.13 & 0.34 & 0.20 & 0.31 & 0.12 & -0.02 & 0.01 & 0.09 \\
\hline 10 & STATEOWN & 0.13 & 0.34 & -0.07 & -0.03 & -0.04 & 0.04 & -0.01 & 0.03 \\
\hline 11 & $M N E \_E X P$ & 0.03 & 0.13 & 0.11 & 0.08 & 0.10 & 0.03 & 0.10 & 0.03 \\
\hline 12 & $M B A$ & 11.56 & 27.46 & 0.05 & -0.02 & 0.07 & 0.00 & 0.04 & 0.06 \\
\hline 13 & BESTPRACTICE & 3.77 & 0.79 & 0.09 & -0.00 & 0.00 & 0.05 & 0.02 & 0.03 \\
\hline 14 & CONSULT & 0.06 & 0.24 & 0.02 & 0.20 & 0.15 & 0.15 & 0.05 & 0.04 \\
\hline 15 & DEMOCRAT & 0.24 & 0.25 & 0.07 & 0.01 & 0.15 & 0.08 & 0.10 & 0.03 \\
\hline 16 & ORGLEVELS & 15.38 & 28.48 & -0.03 & 0.07 & 0.02 & -0.02 & -0.02 & -0.01 \\
\hline 17 & COMP & 3.47 & 0.76 & 0.06 & -0.01 & -0.02 & 0.03 & 0.03 & -0.04 \\
\hline 18 & COMP_MNE & 0.50 & 0.50 & -0.55 & 0.02 & -0.02 & 0.09 & 0.06 & -0.07 \\
\hline
\end{tabular}

In the sample 23.4 percent of the firms are exporters, 6.9 percent has foreign affiliates, and 9.2 outsource to other countries. Certainly, there is much variation in international activities across the transition countries. For example, Bulgaria, Lithuania, Poland and Romania, countries that have adopted massive market reforms and are now part of the European Union, have the highest share of exporting firms: for each EU Member, more than a third of the firms is counted as exporter, whereas the lowest shares are found in Kazakhstan and 
Russia with less than ten percent exporters. Lithuania and Poland also have relatively the most firms with establishments abroad, with average shares above 15 percent, while in Ukraine and Uzbekistan only about one percent of the firms is engaged in FDI. Outsourcing towards other countries is (by far) most common in Lithuania where 47.0 percent of the firms outsource and, least common in Uzbekistan where less than one percent outsources. An observation is that on average internationalization patterns tends to follow transition towards a market economy, explaining to a large extent the difference between countries (see Appendix 1).

To match firms, we use a parsimonious set of variables that capture differences in internationalization and innovation. To match on propensity of internationalization, it is common to use firm size and industry dummies, which account for a large share of variation across firms. As argued, institutional legacy is potentially an important determinant in explaining the variation in internationalization and innovation, therefore we include some factors that capture such differences across firms. For the data give information on managerial practices, stakeholders and competitive environment, we are able to paint a picture of conditions within the firm that relate to such a legacy. More specific we include measures for perceived organization excellence by employees and managerial capabilities, formal involvement of state and foreign actors, and, number and presence of domestic and foreign competitors within the firm's main market. Further, differences in institutions at the country level may at the firm-level explain the variation in organizational legacy, internationalization strategies and innovation. Therefore, firms are only matched with other firms that at located in countries that have a comparable score for the transition phase (see Appendix 1).

\section{RESULTS}

We start by presenting the first stage results for the matching process. To keep the matching equation parsimonious, we have worked from general to specific. Table 2 shows that both firm size as well as the organizational characteristics correlate with internationalization. Appendix 3 shows that including the organizational characteristics is crucial for the matching procedure. For example, with respect to R\&D, including organizational excellence on top of firm size in the first stage allows us to avoid matching large firms with very different legacies, which in itself could capture the differences in 
internationalization and thus innovation. The results show that this substantially reduces the bias in the matching procedure and thus alters the results in the second stage.

Table 2: First stage probit regression results

\begin{tabular}{|c|c|c|c|}
\hline & 1 & 2 & 3 \\
\hline & EXPORT & $F D I$ & OUTSOURCE \\
\hline \multirow[t]{2}{*}{$S I Z E$} & $0.251 * * *$ & $0.198 * * *$ & 0.0869 \\
\hline & {$[0.0562]$} & {$[0.0615]$} & {$[0.0645]$} \\
\hline \multirow[t]{2}{*}{ UNIQUENESS } & $0.265 * * *$ & & \\
\hline & {$[0.0509]$} & & \\
\hline \multirow[t]{2}{*}{ FOREIGNOWN } & $0.555 * * *$ & $1.192 * * *$ & $0.349 * *$ \\
\hline & {$[0.133]$} & {$[0.133]$} & {$[0.156]$} \\
\hline \multirow[t]{2}{*}{ STATEOWN } & $-0.367 * *$ & & -0.307 \\
\hline & {$[0.150]$} & & {$[0.212]$} \\
\hline \multirow[t]{2}{*}{$M N E_{-} E X P$} & & & $0.613 *$ \\
\hline & & & {$[0.325]$} \\
\hline \multirow[t]{2}{*}{$M B A$} & $0.00342 *$ & & $0.00482 * * *$ \\
\hline & {$[0.00192]$} & & {$[0.00178]$} \\
\hline \multirow[t]{2}{*}{ BESTPRACTICE } & $0.150 * *$ & & \\
\hline & {$[0.0677]$} & & \\
\hline \multirow[t]{2}{*}{ CONSULT } & & $0.757 * * *$ & $0.637 * * *$ \\
\hline & & {$[0.172]$} & {$[0.188]$} \\
\hline \multirow[t]{2}{*}{ DEMOCRAT } & & & $0.876 * * *$ \\
\hline & & & {$[0.209]$} \\
\hline \multirow[t]{2}{*}{ COMP } & $0.250 * * *$ & & \\
\hline & {$[0.0787]$} & & \\
\hline \multirow[t]{2}{*}{ COMP_MNE } & & $0.162 *$ & \\
\hline & & {$[0.103]$} & \\
\hline No. Firms & 951 & 1343 & 1081 \\
\hline $\mathrm{Chi}^{2}$ & 118.9 & 128.6 & 80.41 \\
\hline Pseudo $\mathrm{R}^{2}$ & 0.171 & 0.198 & 0.116 \\
\hline
\end{tabular}

Note: $* * * \mathrm{p}<0.01, * * \mathrm{p}<0.05, * \mathrm{p}<0.10$. Robust standard errors in brackets. Sector dummies included, but not presented here.

The main results of the paper are presented in Table 3 . In general, the internationalization of the firm spurs innovation. The findings show a significant effect of exporting on all three measures of innovation: R\&D, product innovation, and international patents. The absolute differences in the average treatment effects between the treated and the comparison group for these innovation variables are 8.1, 4.7 and 8.0 percent respectively. In economic terms this means that exporting firms have a 20.0 percent higher probability to invest in R\&D, earn a 24.1 percent larger share of sales from new developed products, and are 81.9 percent more likely to hold intellectual property abroad in the form of international patents.

FDI has a significant impact on R\&D and international patents. The difference in the average treatment effect for R\&D between firms engaged in FDI and matched counterparts is 15.8, 
which implies that firms that have affiliations abroad on average have a 41.5 percent higher chance of being included in the firms that devote a significant share of their resources to R\&D investments - when compared to similar firms that do not have affiliations abroad. Further these firms have substantially more international patents, as shown by the difference in average treatment effect between the treated and control of 23.8 percent. This converts in the right panel to a 263.6 percent higher probability of owning such patents. The results show that outward FDI is not connected to higher sales from product innovation.

We find no impact of outsourcing on R\&D and international patents, but outsourcing has a significant effect on product innovation. The mean absolute difference is average treatment effect on the treated compared to the control is 4.7 percent for the share of sales from product innovation. The effect size of outsourcing on the share of sales from product innovation is 20.1 percent, meaning that on average outsourcing firms earn 20.1 percent more as the share of sales from new products.

\section{Table 3: The impact internationalization on innovation}

\begin{tabular}{|c|c|c|c|c|c|c|}
\hline & \multicolumn{2}{|c|}{ Panel A: ATE (mean difference) } & \multicolumn{4}{|c|}{ Panel B: estimated effect size } \\
\hline & $R \& D$ & PROD_INNOV & PATENT & $R \& D$ & PROD_INNOV & PATENT \\
\hline EXPORT & $0.08 * *$ & $4.7^{*}$ & $0.08^{* *}$ & $20.0 \% * *$ & $24.1 \% *$ & $81.9 \% * *$ \\
\hline$F D I$ & $0.16 * * *$ & 1.6 & $0.24 * * *$ & $41.5 \% * * *$ & $7,1 \%$ & $263.6 \% * * *$ \\
\hline OUTSOURCE & 0.07 & $4.7 *$ & 0.06 & $14.9 \%$ & $20.1 \% *$ & $42.7 \%$ \\
\hline
\end{tabular}

Overall, the key finding as presented in Table 3 is that internationalization of the firm is key to the understanding the variation in firm productivity. This study provides evidence that exports, foreign affiliates and international subcontracting activities have a large impact on innovation, which is seen a chief determinant of firm productivity and economic growth. These outcomes are not sensitive to the particular matching procedure applied (for robustness tests, see Appendix 3).

\section{CONCLUSION}

This is the first study that explores the different impacts of exporting, FDI and outsourcing on innovation using firm-level data. Overall, exporting raises innovation across the board. This result fits into the learning-by-exporting thesis, which argues that contact with foreign 
partners allows firms to tap into more diverse knowledge and improve the technological capabilities of the firm. In addition, the findings show a positive impact of FDI on R\&D and international patents. This suggests that foreign affiliates transfer technological inputs and increase the absorptive capacity of the firm through R\&D investment. Also, firms with foreign affiliates protect their intellectual property outside the domestic market. However, there is no relationship between FDI and importance of product innovation.

Although we use a broad survey that covers multiple countries, as we use cross-sectional data, it is difficult to convince that we are presenting causal relations. Certainly, future research may use time series data, however, for the moment we are restricted to timeinvariant results from questionnaires. Studies that use secondary databases to create timeseries often have to rely on proxies for internationalization and productivity that may lack credibility of capturing the true within firm effects of innovation. Further, especially in the context of transition economies a common problem is the potential for unobserved variables to affect the results of the estimation. However, we make use of one of the first wellvalidated datasets for these countries that offers detailed firm-level information about management, organization and innovation.

Our study offers micro-level evidence of the benefits of trade liberalization and integration in the world economy for transition economies. Reducing barriers to trade to firms from these countries, for example, through membership of the European Union, has a positive effect and lasting effect on the productivity levels of firms. Moreover, trade reforms in transition economies spur the adaptation of new technologies and firm growth. If the microevidence of this paper translates into macro effects, we may conclude that for middle income countries globalization fosters economic development.

\section{References}

Albornoz-Crespo, F., H.F. Calvo Pardo, G. Corcos and E. Ornelas (2010) 'Sequential Exporting', CEPR Discussion Papers 8103.

Amiti, M and J. Konings (2007) 'Trade Liberalization, Intermediate Inputs, and Productivity: Evidence from Indonesia', American Economic Review, 97(5): 1611-1638.

Arkolakis, C. (2010) 'Market Penetration Costs and the New Consumers Margin in International Trade', Journal of Political Economy, 118(6): 1151-1199.

Arkolakis, C. (2011) 'A Unified Theory of Firm Selection and Growth', NBER Working Paper No. 17553.

Arkolakis, C. and M.A. Muendler (2010) 'The Extensive Margin of Exporting Products: A Firm-Level Analysis', NBER Working Paper No. 16641. 
Arnold, J.M. and K. Hussinger (2005) 'Export Behavior and Firm Productivity in German Manufacturing: A Firm-Level Analysis', Review of World Economics, 141(2), 219-243.

Aw, B.Y., M.J. Roberts and T. Winston (2007) 'Export Market Participation, Investments in R\&D and Worker Training, and the Evolution of Firm Productivity' The World Economy, 30(1): 83-104.

Aw, B.Y., M.J. Roberts and D.Y. Xu (2008) 'R\&D Investments, Exporting, and the Evolution of Firm Productivity', American Economic Review, 98(2): 451-456.

Aw, B.Y, M.J. Roberts and D.Y. Xu (2011) 'R\&D Investment, Exporting, and Productivity Dynamics', American Economic Review 101(4): 1312-1344.

Baldwin, J.R. and W. Gu (2003) 'Export-Market Participation and Productivity Performance in Canadian Manufacturing', Canadian Journal of Economics, 36(3): 634-657.

Baldwin, R.E. and F. Robert-Nicoud (2008) 'Trade and Growth with Heterogeneous Firms', Journal of International Economics, 74(1): 21-34.

Berglöf, E., L. Bruynooghe, H. Harmgart, P. Sanfey, H. Schweiger and J. Zettelmeyer (2010) 'European Transition at Twenty: Assessing Progress in Countries and Sectors', UNI-WIDER Working Paper No. 2010/91.

Bernard, A.B. and J.B. Jensen (1999) 'Exceptional Exporter Performance: Cause, Effect, or Both?', Journal of International Economics, 47(1): 1-25.

Bernard, A.B. and J.B. Jensen (2004) 'Why Some Firms Export', Review of Economic Studies, 86(2): 561-569.

Bernard, A.B., J.B. Jensen, S.J. Redding and P.K. Schott (2011) 'The Empirics of Firm Heterogeneity and International Trade', NBER Working Paper No. 17627.

Blalock, G. and P.J. Gertler (2004) 'Learning From Exporting Revisited in a Less Developed Setting', Journal of Development Economics, 75(2): 397-416.

Bloom, N. and J. Van Reenen (2010) 'Why do management practices differ across firms and countries?' Journal of Economic Perspectives, 24(1): 203-224.

Bloom, N., H. Schweiger and J. Van Reenen (2011) 'The Land that Lean Manufacturing Forgot? Management Practices in Transition Countries', NBER Working Paper No. 17231.

Bustos, P. (2011) 'Trade Liberalization, Exports, and Technology Upgrading: Evidence on the Impact of MERCOSUR on Argentinean Firms', American Economic Review, 101(1): 304-340.

Castellani, D. and A. Zanfei (2007) 'Internationalisation, Innovation and Productivity: How Do Firms Differ in Italy?', The World Economy, 30(1): 156-176.

Clerides, S.K., S. Lach and J.R. Tybout (1998) 'Is Learning by Exporting Important? Micro-dynamic Evidence from Colombia, Mexico, and Morocco', Quarterly Journal of Economics, 113(3): 903947.

Criscuolo, C., J.E. Haskel and M.J. Slaughter (2010) 'Global Engagement and the Innovation Activities of Firms', International Journal of Industrial Organization, 28(2): 191-202.

Damijan, J.P., J. De Sousa and O. Lamotte (2009) 'Does International Openness Affect the Productivity of Local Firms?', Economics of Transition, 17(3): 559-586. 
Damijan, J.P., Č. Kostevc and S. Polanec (2010) 'From Innovation to Exporting or Vice Versa?', The World Economy, 33(3): 374-398.

Damijan, J.P. and Č. Kostevc (2010) 'Learning from Trade Through Innovation: Causal Link Between Imports, Exports and Innovation in Spanish Microdata', LICOS Discussion Paper No. 264.

Dehejia, R.H. and S. Wahba (2002) 'Propensity Score-Matching Methods for Nonexperimental Causal Studies', Review of Economics and Statistics, 84(1): 151-161.

De Loecker, J. (2007) 'Do Exports Generate Higher Productivity? Evidence from Slovenia', Journal of International Economics, 73(1): 69-98.

Djankov, S. and P. Murrell (2002) 'Enterprise Restructuring in Transition: A Quantitative Survey', Journal of Economic Literature, 40(3): 739-792.

Eaton, J., M. Eslava, M. Kugler, and J. Tybout (2008) 'The Margins of Entry Into Export Markets: Evidence from Colombia', in Helpman, E., D. Marin and T. Verdier (Eds.), The Organization of Firms in a Global Economy, Harvard University Press, Massachusetts.

Estrin, S., J. Hanousek, E. Kočenda and J. Svejnar (2009) 'The Effects of Privatization and Ownership in Transition Economies', Journal of Economic Literature, 47(3): 699-728.

Filatotchev, I., M. Wright, K. Uhlenbruck, L. Tihanyi and R.E. Hoskisson (2003) 'Governance, Organizational Capabilities, and Restructuring in Transition Economies', Journal of World Business, 38(4): 331-347.

Filatotchev, I., J. Stephan and B. Jindra (2008) 'Ownership Structure, Strategic Controls and Export Intensity of Foreign-invested Firms in Transition Economies', Journal of International Business Studies, 39(7): 1133-1148.

Garciá, F., L. Avella and E. Fernández (forthcoming) 'Learning from Exporting: The Moderating Effect of Technological Capabilities', International Business Review, in press.

Gelbuda, M., K.E. Meyer and A. Delios (2008) 'International Business and Institutional Development in Central and Eastern Europe', Journal of International Management, 14(1): 1-11.

Girma, S., D. Greenaway and R. Kneller (2004) 'Does Exporting Increase Productivity? A Microeconometric Analysis of Matched Firms', Review of International Economics, 12(5): 855866.

Goldberg, P.K., A.K. Khandelwal, N. Pavcnik and P. Topalova (2010) 'Imported Intermediate Inputs and Domestic Product Growth: Evidence from India', Quarterly Journal of Economics,125(4): 1727-1767.

Hagemejer, J. and M. Kolasa (2011) 'Internationalisation and Economic Performance of Enterprises: Evidence from Polish Firm-Level Data', The World Economy, 34(1): 74-100.

Hagemejer, J. and J. Tyrowicz (2012) 'Is the Effect Really So Large? Firm-Level Evidence on the Role of FDI in a Transition Economy', Economics of Transition, 20(2): 195-233.

Helpman, E., M.J. Melitz and S.R. Yeaple (2004) 'Export Versus FDI with Heterogeneous Firms', American Economic Review, 94(1): 300-316.

Impullitti, G. and O. Licandro (2010) 'Trade, Firm Selection, and Innovation: The Competition Channel', UFAE-IAE Working Paper, No. 841.10. 
Kafouros, M.I., P.J. Buckley, J.A. Sharp and C. Wang (2008) 'The Role of Internationalization in Explaining Innovation Performance', Technovation, 28(1): 63-74.

Kasahara, H. and J. Rodrigue (2008) 'Does the Use of Imported Intermediates Increase Productivity? Plant-level Evidence', Journal of Development Economics, 87(1): 106-118.

Krammer, S.M.S. (2009) 'Drivers of National Innovation in Transition: Evidence from a Panel of Eastern European Countries', Research Policy, 38(5): 845-860.

Kriauciunas, A. and P. Kale (2006) 'The Impact of Socialist Imprinting and Search on Resource Change: A Study of Firms in Lithuania', Strategic Management Journal, 27(7): 659-679.

Lileeva, A. and D. Trefler (2010) 'Improved Access to Foreign Markets Raises Plant-Level Productivity... for Some Plants', Quarterly Journal of Economics, 125(3): 1051-1099.

Lyles, M.A. and J. Salk (1996) 'Knowledge Acquisition from Foreign Parents in International Joint Ventures: An Empirical Examination in the Hungarian Context', Journal of International Business Studies 27(5): 877-903.

Marinov, M.A. and S.T. Marinova (2011) The Changing Nature of Doing Business in Transition Economies, New York: Palgrave Macmillan.

Mayer, T., M.J. Melitz and G.I.P. Ottaviano (2011) 'Market Size, Competition, and the Product Mix of Exporters', NBER Working Paper No. 16959.

Melitz, M.J. (2003) 'The Impact of Trade on Intra-Industry Reallocations and Aggregate Industry Productivity', Econometrica, 71(6): 1695-1725.

Melitz, M.J. and J.A. Costantini (2008) 'The Dynamics of Firm Level Adjustment to Trade Liberalization', in Helpman, E., D. Marin and T. Verdier (Eds.), The Organization of Firms in a Global Economy, Harvard University Press, Massachusetts.

Melitz, M.J. and G.I.P. Ottaviano (2008) 'Market Size, Trade, and Productivity', Review of Economic Studies, 75(1): 295-316.

Meyer, K.E. and M.W. Peng (2005) 'Probing Theoretically into Central and Eastern Europe: Transactions, Resources, and Institutions', Journal of International Business Studies, 36(6): 600-621.

Monreal-Pérez, J., A. Aragón-Sánchez and G. Sánchez-Marín (forthcoming) 'A Longitudinal Study of the Relationship Between Export Activity and Innovation in the Spanish Firm: The Moderating Role of Productivity', International Business Review, in press.

Navaretti, B.G. and D. Castellani (2004) 'Investments Abroad and Performance at Home: Evidence from Italian Multinationals', CEPR Discussion Papers 4284.

Newman, K.L. (2000) 'Organizational Transformation During Institutional Upheaval', Academy of Management Review, 25(3): 602-619.

Pavcnik, N. (2002) 'Trade Liberalization, Exit, and Productivity Improvement: Evidence from Chilean Plants' Review of Economic Studies, 69(1), 245-76.

Roberts, M.J. and J.R. Tybout (1997) 'The Decision to Export in Colombia: An Empirical Model of Entry with Sunk Costs', American Economic Review, 87(4): 545-564. 
Rojec, M., J.P. Damijan and B. Majcen (2004) 'Export Propensity of Estonian and Slovenian Manufacturing Firms', Eastern European Economics, 42(4): 33-54.

Rosenbaum, P.R. and D.B. Rubin (1983) 'The Central Role of the Propensity Score in Observational Studies for Causal Effects', Biometrika, 70(1): 41-55.

Rosenbaum, P.R. and D.B. Rubin (1985) 'Constructing a Control Group Using Multivariate Matched Sampling Methods That Incorporate the Propensity Score', The American Statistician, 39(1): 33-38.

Salomon, R.M. and J.M. Shaver (2005) 'Learning by Exporting: New Insights from Examining Firm Innovation', Journal of Economics \& Management Strategy, 14(2): 431-460.

Salomon, R. and B. Jin (2010) 'Do Leading or Lagging Firms Learn More from Exporting?', Strategic Management Journal, 31(10): 1088-1113.

Smith, J.A. and P.E. Todd (2005) 'Does Matching Overcome LaLonde's Critique of Nonexperimental Estimators?', Journal of Econometrics, 125(1-2): 305-353.

Steensma, H. K., J.Q. Barden, C. Dhanaraj, M.A. Lyles and L. Tihanyi (2008) 'The Evolution and Internalization of International Joint Ventures in a Transitioning Economy', Journal of International Business Studies, 39(3): 491-507.

Svejnar, J. (2002) 'Transition Economies: Performance and Challenges', Journal of Economic Perspective, 16(1): 3-28.

Van Biesebroeck, J. (2005) 'Exporting Raises Productivity in Sub-Saharan African Manufacturing Plants', Journal of International Economics, 67(2): 373-391.

Verhoogen, E.A. (2008) 'Trade, Quality Upgrading, and Wage Inequality in the Mexican Manufacturing Sector', Quarterly Journal of Economics, 123(2): 489-530.

Wagner, J. (2002) 'The Causal Effect of Exports on Firm Size and Labor Productivity: First Evidence From a Matching Approach', Economics Letters, 77(2): 287-292.

Wagner, J. (2007) 'Exports and Productivity: A Survey of the Evidence from Firm Level Data', The World Economy, 30(1): 60-82.

Wagner, J. (2011) 'International Trade and Firm Performance: A Survey of Empirical Studies Since 2006', IZA Discussion Paper, 5916.

WTO (2008) 'World Trade Report 2008: Trade in a Globalizing World', Geneva: World Trade Organization.

Yeaple, S.R. (2005) 'A Simple Model of Firm Heterogeneity, International Trade, and Wages', Journal of International Economics, 65(1): 1-20. 


\section{Appendix 1}

In this Appendix 1 we explain in detail how each of the variables employed in this study is measured. In particular, we use measurements for internationalization, innovation and a set of controls that focus on transition and legacy related variables. For further details, see Table 1 for summary statistics and correlations among the key variables.

\section{Operationalization}

Internationalization: In the survey two top managers respond to question items related to exporting, FDI and international outsourcing. First, EXPORT is measured using a variable that indicates if the firm sells its main product mostly abroad, that is, most sales are international. This assignment means that there are firms grouped as "not exporting" that may sell a part of their production abroad and may potentially be large exporters in volume. Qualitative, the export indicator applied here shows if the domestic production of the firm is focused on exporting the product. In our sample 23.4 percent of the firms report that their sales are mainly international and are thus counted as "exporters". Second, FDI is also a dummy variable which shows whether the firm has any establishments abroad based on the specification of the total number of establishments that the firm has abroad. As such, this variable picks up if the firm has any foreign affiliation but not the importance of the outward orientation, simply because there is no information about the sales generated in each foreign affiliates. On average, in our sample only 6.9 percent of the firms indicates that they have one or more than one establishments abroad and are thus classified as engaged in FDI. The median number of establishment for these firms is three foreign affiliates. Third, OUTSOURCE indicates whether or not the establishment subcontracts production to another country. That is, only international subcontracting activities are captured in our outsourcing measure. By this definition outsourcing does not include production activities that the firm does for a foreign partner, because this would be included in the exports variable. In our sample 9.2 percent of the firms outsource, with Germany as most frequent destination.

Innovation: we focus on three innovation measures, namely $R \& D$, sales from product innovation and international patents. First, the $R \& D$ measure is constructed using information about whether the firm invests in research and development (R\&D), defined as creative work undertaken systematically to increase firm knowledge. In the sample 37.8 percent of the firms invests in R\&D. Second, PROD_INNOV is a measure of the share of sales attributed to new products and services that were introduced over the past three years. In total 67.4 percent has launched new products or services. Of these firms, on 
average the share of annual sales accounted for by these new products and services that were recently introduced is 30.1 percent, with a median share of sales of 20.0 percent. Third, PATENT is a dummy variable that measures whether the firm has any registered patents abroad. In total, 8.0 percent of the firms has any such international intellectual property right protection in the form of a patent or patents.

Control variables: in this study we use two types of control variables. To start we use a small set of key firm and industry characteristics that are common in the internationalization literature and also correlate with innovation measures. SIZE is the log of the number of employees. Also, top managers estimate to what extent the firm produces unique products and services. Specifically, UNIQUENESS measures on a five-point ordinal scale how long it would take the largest customer of the firm to find an alternative supplier for its main product if the establishment shuts down its business. In addition, eight industry dummies are included: CHEMICALS (4.0 percent), CLOTHING (garments and textiles, 14.4 percent), ELECTRONICS (4.4 percent), FOODS (15.7 percent), MACHINERY (9.1 percent), METALLURY (13.9 percent), PLASTICS (4.2 percent), and 'other manufacturing' (34.3 percent) is used as baseline.

In addition, a rich set of control variables employed in this research is connected to the degree of institutional legacy faced by the firm after the transition phase towards a marketled economy. In transition economies, the legacy is potentially an important factor that affects internationalization and innovation of the firm. This second type of firm characteristics focuses on management and organizational features that may signify the degree of legacy (see Section 2.2).

First, we include two variables about the ownership of the firm. Firms that are still stateowned enterprises may witness greater legacy effects than firms that are currently owned by foreigners. FOREIGNOWN is a dummy variable that indicates if a foreign owner holds the largest single stake in the firm, where the foreign investor (individual, family, or firm) must hold a largest share of at least 25 percent in the firm. STATEOWN measures state ownership of the firm for at least the past three years. Firms were asked if the 'national' state was largest owner three years ago, and, whether this has changed.

Apart for these measures, we use information about six other management and organization variables. Firms that have managers with prior work experience at 
multinationals, business education or who adopted best managerial practices, or hire consultants to improve the management, and who are more open to ideas from worker are expected to have moved further in transition process and, hence, have a lower legacy at the firm-level. MNE_EXP captures the share of top managers that have prior work experience at a multinational organization. MBA measures the share of top managers with a Master of Business Administration degree. BESTPRACTICE is used as a measure of organizational excellence. More specific, each top manager was asked to indicate how well-managed the firm is using a five-point scale of best practices in terms of three items, namely people management (promotions, rewards, hiring people, etc.), operations management (processes, production, etc.) and in overall terms. Another variable that relates to the degree of legacy as well as the internationalization and innovation measures is CONSULT, which indicates if the firm recently hired an external consultant to help improve any area of the management of the firm. A five item scale DEMOCRAT (Cronbach's alpha $=0.63$ ) measures if management asks employees for their opinion with regard to decisions about i) working hours, ii) days of factory holidays, iii) employing new workers, iv) making investment decisions (purchasing fixed assets), and, v) setting prices. ORGLEVEL measures the number of hierarchical levels in the chain of command structure of the firm, which can be thought of as an indicator of the degree of decentralization. Finally, we use information about the competitive environment of the firm because more competitive pressure is indicative of a greater movement away from the state-led economy. COMP is a four-point ordinal measure that captures how many competitors the firm faces in its main product market. COMP_MNE is a dummy variable that indicates if there are any multinational firms producing in the same main market.

Transition Indicator: firm-level, market, and sector differences capture much of the variation in legacy to the transition. Still, it is important to consider how much countries have commenced towards democracy and market-based economies. For instance, Krammer (2009) looks at the drivers of innovation in Eastern Europe. He stipulates the wide regional differences in institutional heritage and commitment to technological upgrading before and after the regime shift. His results indicate that more favourable business climate, intellectual property rights protection and foreign investments increase the number of patents, implying that the institutional legacy is an important factor to account for. On a five-point scale, the EBRD provides a Transition Indicator for each country which gives a score on the progression to a "well-functioning" market economy. The scores over 29 transition countries range between 1.4 and 4.0, where we categorize countries with a score below a 3.0 as 
"low", those with a score between 3.0 and 3.5 as "medium" and those with 3.5 or higher as "high" (see Berglöf et al., 2010).

Table A1 presents an overview of the transition phase groups and a summary of the key variables. As can be seen, the firms in transition countries that have restructured their economies the most also obtain on average the highest scores on internationalization and innovation. Also, firms in the low transition group are in general among the least internationalized and innovative, although the differences with the medium group are not significant for most measures. So, the institutional context of the firm's geographic environment is important for the tendency to internationalize and innovate.

Table A1: Summary statistics of key variables by transition phase

\begin{tabular}{|c|c|c|c|c|c|c|c|c|}
\hline \multicolumn{2}{|c|}{ transition countries } & \multirow[t]{2}{*}{ Obs. } & \multirow[t]{2}{*}{ EXPORT } & \multirow[t]{2}{*}{$F D I$} & \multirow[t]{2}{*}{ OUTSOURCE } & \multirow[t]{2}{*}{$R \& D$} & \multirow[t]{2}{*}{ PRODUCT } & \multirow[t]{2}{*}{ PATENT } \\
\hline low & Belarus, Kazakhstan, & & & & & & & \\
\hline & Serbia, Uzbekistan & 485 & 0.15 & 0.06 & 0.04 & 0.32 & 16.55 & 0.07 \\
\hline medium & Romania, Russia, Ukraine & 513 & 0.16 & 0.04 & 0.06 & 0.37 & 18.90 & 0.06 \\
\hline high & Bulgaria, Lithuania, Poland & 357 & 0.45 & 0.12 & 0.20 & 0.45 & 23.79 & 0.11 \\
\hline
\end{tabular}




\section{Appendix 2}

\section{A2.1. Matching properties}

In this Appendix 2 we provide some details about the matching properties. In particular, we check if there is a balance between the treated and comparison firms, because after matching the treated and controls should be "statistically equivalent". Propensity score matching aims to find a proper a comparison group that is statistically equivalent to the internationalized firm, except for the treatment (here: internationalization). Finding such firms is difficult because of non-random assignment to the treatment; that is, firms that choose to internationalize are different and tend to self-select into international activities. Hence, on average, firms that are not international are unlikely to be a good comparison for the treated group because of selection bias. For example, larger firms have a higher probability to internationalize, and thus comparison between the treated and non-treated is biased, because it is easier for larger firms to engage in innovation related activities (the outcome). Simple OLS regression techniques cannot be applied. So, when evaluating the impact of internationalization on differences in innovation between the treated and untreated, it is difficult to isolate the effect of internationalization because of self-selection into internationalization. The key benefit of propensity score matching is that it accounts and adjusts for these innate dissimilarities across international and non-international firms (Dehejia and Wahba, 2002). Internationalized firms are matched with individual firms that are not internationalized based on an estimated probability that the firm would internationalize (the propensity score), hence it requires selection on observables and the existence of an untreated firm that can be compared to a treated firm. In absence of randomization, the groups must differ not only in terms of international activities, but also on their values of the observed characteristics in order to extract propensity scores.

A first requirement of matching is to account for these differences in observables by controlling for a set of covariates (conditional independence). More formally, there must be a set of observable covariates such that when accounting for this set, the potential outcomes are independent of the treatment status. Hence, after controlling for several observables, the selection into the internationalization of the firm "looks" random; this is essential of the 'construction' of a counterfactual.

A second requirement is that firms can be sufficiently matched to counterparts such that there is overlapping between the observable characteristics of the treated and the untreated firms (common support). Formally, common support means that for each value (or range) 
of the covariates, there is a positive probability of being both treated and untreated to ensure substantial overlap in the characteristics of international and not-international firms.

To estimate the propensity score a probit model can be used, given that the treatment is dichotomous. The set of $X$ must include all relevant covariates that relate to both internationalization as well as the outcome (here: innovation), which produces the specification of the selection model (see Table 2). Following Rosenbaum and Rubin (1983), satisfying the conditional independence and common support assumptions implies that the treatment assignment is "strongly ignorable". One setback in cross-sectional data is that the measures applied as controls may be confounded with the outcome variable or the anticipation of the treatment. However, it has been established that the quality of matching is not influenced by a high correlation between the controls and the outcome. Furthermore, the inclusion of irrelevant variables that not affect internationalization is best avoided because they increase the variance of the estimates and may give problems to the common support.

\section{A2.2. Balancing tests}

The balancing property of the matching procedure can be tested by looking at the differences between the covariate means of the treatment and comparison group before and after matching. Simple $t$-tests of equality of the mean can evaluate if propensity score matching succeeds in balancing the characteristics between treated and untreated firms. For our purpose it is important that the transition and legacy related variable make a significant contribution to the matching properties on top of the standard firm and industry characteristics. There are several indications that this is the case, such that matching firms without these variables would lead to a biased comparison group. That is, we may compare large firms that are internationally active to another firm of similar size that is not internationally active, where the former turns out to be foreign owned and the latter state owned. In the context of transition one may doubt if such comparison is warranted.

For each international firm, its comparison firm or counterpart is the untreated (noninternational) firm with the most similar characteristics (in terms of the value of $X$ ). Here the propensity score is calculated, which is the probability of internationalization given $X$, or $P(D=1 \mid X)$. To test the quality of the matching under the conditional independence assumption, covariate imbalance testing checks if the estimated propensity scores adequately balance the characteristics between the treatment and the control group firms by evaluating the difference in covariate means (see Rosenbaum and Rubin, 1985). As 
Rosenbaum and Rubin (1983) show, if it is appropriate to match firms based on covariates $X$, then it is also valid to match on simply the propensity score $p(\mathrm{X})$. That is, strongly ignorable treatment allocation (SITA) means that $p(X)=P(D=1 \mid X)$ and therefore avoids the curse of dimensionality because matching is done on the propensity score only which contains all relevant information over the set of covariates in relation to the treatment.

Overall, results suggest a high quality of the matches between exporters and non-exporters, firms engaged in FDI and those that do not, and, outsourcing firms and non-outsourcing firms on a set of observable variables that are significant in the first stage probit regressions in explaining the internationalization of firms (see Table A2.1 to Table A2.6). ${ }^{7}$

Table A2.1 and Table A2.2 present the mean differences between the variables on which exporters are matched with non-exporters for each innovation measure. As expected, there are significant ex ante differences between exporters and non-exporters in terms of observables that can explain the self-selection of firms into export participation. Exporters are larger, have more unique products, are more often foreign owned, score higher on organizational excellence, and, face greater competition than non-exporters. Also, the exporters are less often state-owned than non-exporters. There are no difference in terms of the share of managers with a MBA. After matching firms the characteristics between exporters and non-exporters are negligible. Notice that after matching the treated group of exporters even scores lower on best practices and is more often state-owned than nonexporters. This type of overcompensation is important because apparently these transition and legacy variables are very different between exporters and non-exporters even while conditioning on the other variables. A similar issue happens in relationship to the share of managers with a MBA. As such, to ensure a high quality match, we only observe, say, large exporters and large non-exporters where the former has a much greater likelihood not to be state-owned. Combined, this set of variables play a significant role in the first stage probit estimations of export participation (see Table 2).

\footnotetext{
7 Rosenbaum and Rubin (1985) also suggest that the standardized difference can be calculated, which is the size of the difference in means of the covariate between the treatment and comparison firms scaled by the square root of the average of the sample variances. As long as the standardized difference for each covariate is lower than 20, the differences between the treated and controls are small. For the matching of exporters and non-exporters, none of the standardized difference of any covariate was larger than 20. Before matching, the average differences across six covariates were between 27.69 and 29.06, while after matching this is reduced to average difference between 7.92 and 9.27 . For matching on FDI none of the standardized difference of any covariate was larger than 20. Before matching, the average differences across six covariates were between 48.08 and 49.15 , while after matching this is reduced to average difference between 4.64 and 7.56. Also for outsourcing none of the difference was larger than 20. Before matching the differences ranged on average between 33.92 and 35.14 , and, after matching this was only between 4.78 and 6.98 .
} 
Table A2.3 and Table A2.4 show the average differences between firms that engage in FDI and those that do not before and after they are matched for each innovation variable. As we anticipated, there are ex ante large differences between FDI and non-FDI firms. In general, larger, foreign owned firms, that receive consultation about management practices and have more organizational levels self-select into FDI participation. Only the difference in competition by multinationals is not significant. These observables, including competition by multinationals explain in the first stage probit regressions much of the variation of having any foreign affiliations (see Table 2). After matching on these observables the difference between the treatment and comparison group disappears.

In Table A2.5 and Table A2.6 we find the balancing properties in terms of the mean differences between outsourcing firms and non-outsourcing firms while matched for the three innovation outcomes. Outsourcing firms with partners abroad are very different from their counterparts. Firms that subcontract production abroad are much larger, have a greater share of managers with experience at a multinational, receive more consultation about management practices, are more often owned by foreign investors and, have more a democratic work environment compared to non-outsourcing firms. These factors explain an important part of the self-selection into international subcontracting activities (see Table 2). After matching outsourcing and non-outsourcing firms on these characteristics, there are no differences on these variables such that there is no selection bias on observables. 
Table A2.1. Before matching exporters (unmatched, mean differences)

exporters non-exporters

\section{Panel 1: R\&D}

SIZE

5.31

3.36

0.23

0.11

11.90

3.89

3.59

COMP

Panel 2: Product innovation

SIZE

UNIQUENESS

FOREIGNOWN

STATEOWN

$M B A$

BESTPRACTICE

СOMP

5.29

3.36

0.22

0.11

10.87

3.87

3.57

Panel 3: International patents

SIZE

UNIQUENESS

FOREIGNOWN

STATEOWN

$M B A$

BESTPRACTICE

COMP
4.99

2.81

0.10

0.15

9.92

3.70

3.46

4.97

2.80

0.09

0.15

9.79

3.70

3.47

4.97

2.80

0.09

0.15

9.81

3.69

3.47
$\%$ difference

t-value

$$
\begin{gathered}
4.80 * * * \\
6.53 * * * \\
5.69 * * * \\
-1.60 * \\
0.98 \\
3.30 * * * \\
2.32 * *
\end{gathered}
$$

33.9

4.71***

49.9

6.49***

36.5

$-10.9$

$5.39 * * *$

$-1.39$

0.53

$2.88 * * *$

1.80*
$4.72 * * *$

$6.55 * * *$

5.97***

$-1.67 *$

0.92

$3.22 * * *$

2.04** 
Table A2.2: After matching exporters (matched, mean differences)

\begin{tabular}{|c|c|c|c|c|c|}
\hline & exporters & non-exporters & $\%$ difference & bias reduction $(\%)$ & $\mathrm{t}$-value \\
\hline \multicolumn{6}{|l|}{ Panel 1: R\&D } \\
\hline SIZE & 5.30 & 5.23 & 7.10 & 78.70 & 0.73 \\
\hline UNIQUENESS & 3.34 & 3.37 & -3.30 & 93.10 & -0.39 \\
\hline FOREIGNOWN & 0.21 & 0.25 & -9.00 & 75.60 & -0.85 \\
\hline STATEOWN & 0.11 & 0.07 & 13.10 & -8.60 & 1.65 \\
\hline MBA & 11.88 & 16.94 & -19.6 & -155.6 & $-1.73 *$ \\
\hline BESTPRACTICE & 3.87 & 3.99 & -15.50 & 34.50 & $-1.67 *$ \\
\hline COMP & 3.57 & 3.52 & 7.60 & 55.00 & 0.83 \\
\hline \multicolumn{6}{|c|}{ Panel 2: Product innovation } \\
\hline SIZE & 5.28 & 5.27 & 2.00 & 94.10 & 0.19 \\
\hline UNIQUENESS & 3.34 & 3.35 & -0.80 & 98.40 & -0.09 \\
\hline FOREIGNOWN & 0.20 & 0.25 & -13.50 & 63.00 & -1.21 \\
\hline STATEOWN & 0.11 & 0.07 & 12.80 & -17.90 & 1.55 \\
\hline MBA & 11.18 & 14.94 & -15.1 & -249.5 & -1.28 \\
\hline BESTPRACTICE & 3.86 & 3.96 & -13.10 & 39.20 & -1.38 \\
\hline COMP & 3.56 & 3.52 & 5.30 & 60.70 & 0.55 \\
\hline \multicolumn{6}{|c|}{ Panel 3: International patents } \\
\hline SIZE & 5.27 & 5.18 & 8.80 & 73.50 & 0.89 \\
\hline UNIQUENESS & 3.34 & 3.32 & 1.60 & 96.80 & 0.18 \\
\hline FOREIGNOWN & 0.22 & 0.24 & -7.60 & 80.60 & -0.70 \\
\hline STATEOWN & 0.11 & 0.06 & 13.20 & -2.30 & $1.66 *$ \\
\hline MBA & 11.48 & 16.82 & -21.0 & -185.1 & $-1.80 *$ \\
\hline BESTPRACTICE & 3.87 & 3.98 & -14.60 & 38.20 & -1.53 \\
\hline СОМP & 3.57 & 3.53 & 5.80 & 61.90 & 0.62 \\
\hline
\end{tabular}


Table A2.3. Before matching FDI (unmatched, mean differences)

FDI non-FDI \% difference t-value

Panel 1: R\&D

$\begin{array}{lcccc}\text { SIZE } & 5.50 & 5.00 & 50.6 & 4.89 * * * \\ \text { FOREIGNOWN } & 0.52 & 0.10 & 100.4 & 11.62 * * * \\ \text { CONSULT } & 0.23 & 0.05 & 55.2 & 7.08 * * * \\ \text { ORGLEVELS } & 23.61 & 14.85 & 24.5 & 2.74 * * * \\ \text { COMP_MNE } & 0.54 & 0.49 & 9.6 & 0.86\end{array}$

Panel 2: Product innovation

$\begin{array}{lcccc}\text { SIZE } & 5.48 & 4.99 & 51.9 & 4.58 * * * \\ \text { FOREIGNOWN } & 0.48 & 0.10 & 91.2 & 9.95 * * * \\ \text { CONSULT } & 0.24 & 0.05 & 56.7 & 6.92 * * * \\ \text { ORGLEVELS } & 24.92 & 15.04 & 26.4 & 2.82 * * * \\ \text { COMP_MNE } & 0.56 & .48765 & 14.5 & 1.21\end{array}$

Panel 3: International patents

\begin{tabular}{lcccc} 
SIZE & 5.52 & 4.98 & 54.5 & $5.12 * * *$ \\
FOREIGNOWN & 0.50 & 0.10 & 97.7 & $11.01 * * *$ \\
CONSULT & 0.24 & 0.05 & 57.0 & $7.08 * * *$ \\
ORGLEVELS & 24.32 & 14.90 & 25.6 & $2.79 * * *$ \\
COMP_MNE & 0.55 & 0.49 & 10.9 & 0.93 \\
\hline
\end{tabular}

Table A2.4: After matching FDI (matched, mean differences)

FDI non-FDI $\%$ difference bias reduction (\%) t-value

\section{Panel 1: R\&D}

\begin{tabular}{lccccc} 
SIZE & 5.41 & 5.44 & -3.4 & 93.3 & -0.21 \\
FOREIGNOWN & 0.49 & .50 & -3.8 & 96.2 & -0.20 \\
CONSULT & 0.20 & .19 & 2.1 & 96.2 & 0.11 \\
ORGLEVELS & 24.11 & 22.46 & 4.6 & 81.1 & 0.23 \\
COMP_MNE & 0.55 & .50 & 9.2 & 4.2 & 0.58 \\
Panel 2: Product innovation & 5.41 & 5.45 & & 92.8 & -0.21 \\
SIZE & 0.45 & 0.47 & -3.7 & 93.8 & -0.28 \\
FOREIGNOWN & 0.19 & 0.18 & -5.7 & 88.5 & 0.34 \\
CONSULT & 25.32 & 22.72 & 6.5 & 73.6 & 0.33 \\
ORGLEVELS & 0.56 & 0.49 & 7.0 & -3.2 & 0.89 \\
COMP_MNE & & 14.9 & & -0.19 \\
Panel 3: International patents & 5.42 & 5.45 & & 94.1 & -0.36 \\
SIZE & 0.47 & 0.49 & -3.2 & 92.5 & 0.23 \\
FOREIGNOWN & 0.20 & 0.19 & -7.4 & 92.1 & 0.25 \\
CONSULT & 24.92 & 22.87 & 4.5 & 5.6 & -4.6 \\
ORGLEVELS & 0.56 & 0.51 & 11.4 & 0.68 \\
COMP_MNE & & & & \\
\hline
\end{tabular}


Table A2.5. Before matching outsourcing firms (unmatched, mean differences)

outsource non-outsource \% difference t-value

Panel 1: R\&D

$\begin{array}{lllll}\text { SIZE } & 5.22 & 5.00 & 21.2 & 2.22 * * \\ \text { MNE_EXP } & 0.08 & 0.03 & 28.2 & 3.67 * * * \\ \text { CONSULT } & 0.18 & 0.05 & 40.6 & 5.47 * * * \\ \text { FOREIGNOWN } & 0.24 & 0.12 & 32.0 & 3.76 * * * \\ \text { DEMOCRAT } & 0.36 & 0.22765 & 52.4 & 5.50 * * *\end{array}$

Panel 2: Product innovation

$\begin{array}{lllll}\text { SIZE } & 5.24 & 5.01 & 25.7 & 2.56 * * \\ \text { MNE_EXP } & 0.07 & 0.03 & 24.4 & 2.74 * * * \\ \text { CONSULT } & 0.19 & 0.05 & 45.4 & 5.94 * * * \\ \text { FOREIGNOWN } & 0.22 & 0.11 & 29.2 & 3.21 * * * \\ \text { DEMOCRAT } & 0.36 & 0.23 & 51.1 & 5.02 * * *\end{array}$

Panel 3: International patents

\begin{tabular}{lllll} 
SIZE & 5.23 & 5.01 & 24.5 & $2.49 * *$ \\
MNE_EXP & 0.06 & 0.03 & 24.8 & $2.86 * * *$ \\
CONSULT & 0.17 & 0.05 & 36.8 & $4.68 * * *$ \\
FOREIGNOWN & 0.23 & 0.11 & 32.2 & $3.66 * * *$ \\
DEMOCRAT & 0.36 & 0.23 & 51.4 & $5.19 * * *$ \\
\hline
\end{tabular}

Table A2.6: After matching outsourcing firms (matched, mean differences)

\begin{tabular}{lccccc}
\hline Panel 1: R\&D & FDI & non-FDI & \% difference & bias reduction (\%) & t-value \\
SIZE & & & & & \\
MNE_EXP & 5.19 & 5.20 & -1.9 & 91.0 & -0.14 \\
CONSULT & 0.07 & 0.05 & 13.2 & 53.3 & 0.90 \\
FOREIGNOWN & 0.16 & 0.15 & 3.9 & 90.4 & 0.26 \\
DEMOCRAT & 0.22 & 0.22 & 0.5 & 98.6 & 0.03 \\
Panel 2: Product innovation & 0.35 & 0.36 & -3.9 & 92.6 & -0.27 \\
SIZE & 5.20 & 5.13 & 6.7 & & \\
MNE_EXP & 0.06 & 0.05 & 5.0 & 73.8 & 0.48 \\
CONSULT & 0.17 & 0.13 & 11.3 & 79.5 & 0.31 \\
FOREIGNOWN & 0.20 & 0.20 & -0.5 & 75.2 & 0.71 \\
DEMOCRAT & 0.35 & 0.38 & -10.4 & 98.2 & -0.04 \\
Panel 3: International patents & & & 79.6 & -0.68 \\
SIZE & 5.18 & 5.15 & 3.5 & & \\
MNE_EXP & 0.06 & 0.05 & 8.5 & 85.6 & 0.25 \\
CONSULT & 0.14 & 0.13 & 5.6 & 65.6 & 0.54 \\
FOREIGNOWN & 0.21 & 0.20 & 3.6 & 84.9 & 0.36 \\
DEMOCRAT & 0.35 & 0.36 & -4.7 & 88.9 & 0.24 \\
\hline
\end{tabular}




\section{Appendix 3}

Obviously, after calculating propensity scores for each firm, there are various ways to match international firms to counterparts. First, matching can be done with or without replacement (Dehejia and Wahba, 2002). Second, there are alternative assessment methodologies for the closeness of the match to be considered (see Smith \& Todd, 2005). The problem is that after deriving propensity scores, there is no assurance that a treated firm will have a counterpart that is close enough so some firms may be dropped (see common support requirement, Appendix 2). Third, researcher can weight cases in the analysis, for instance using kernel matching. Finally, the number of comparison firms matched to each treated firm must be determined, for example by specifying the number of nearest neighbors. To interpret the results of the impact, standard errors of propensity score matching estimates are obtained using bootstrapping although this produces error estimates that are asymptotically unbiased, meaning that in small samples there is no guarantee of unbiased estimates.

In this part we re-estimate the main results from Table 3 by relying on several modifications to the matching procedure. It is generally known that the outcomes of matching can be sensitive to relative small adjustments in the matching technique. Therefore, three major changes are implemented yielding 12 different specifications. First, instead of using nearest neighbour matching, two other matching procedures, Epanechnikov kernel, and, one-to-one with no replacement, are applied. Second, we abandon the principle of forced (exact) matching of firms on transition stage of the country. Finally, the first stage covariate list is adjusted. In this case we choose to match firms only on SIZE, AGE and industry characteristics. In addition, in some of the first stage probit regressions we include country dummies (see Table A3, note for details).

Table A3 shows that overall the results are robust. The bottom of Table A3 gives an overview of the simple averages in the mean differences of the average treatment effects across the 12 specifications. These results are highly comparable to the main findings in Table 3. The impact of exporting on R\&D is somewhat lower than in the main results, and only significant in 4 of the 12 alternative specifications. The effect of exporting on the share of sales of product innovation is also lower, but significant in half of the other analyses. The impact of exporting on international patent is on average larger and significant in all of the sensitivity tests. With respect to FDI we find that the mean differences in average treatment effect between firms with foreign affiliates and those without on the innovation measures is 
comparable to the benchmark. As shown at the bottom under AVERAGE, the effect of FDI on $R \& D$ is highly comparable and significant in each alternative specification. The impact of FDI on the product innovation is on average larger when compared to the main results, however, this effect is only significant in two of the analyses. Therefore, the robustness test also show that FDI is not a driver of product innovation. The impact of FDI on international patents is similar to the main finding from Table 3. Here we find a significant effect of FDI on patents in all specifications. Finally, the outcomes show that on average, outsourcing only has a significant impact on product innovation, which is also shown in Table 3 . On average, the impacts on R\&D and international patent are somewhat higher compared to main results, while the effect on product innovation is somewhat lower. In nine of the twelve sensitivity analyses outsourcing is a significant determinant of the share of sales from new products. In contrast, in seven of the twelve specifications we find a significant effect of outsourcing on R\&D and international patents. 


\section{Table A3: Mean differences in ATE on treated and control}

\begin{tabular}{|c|c|c|c|c|}
\hline & Innovation & EXPORT & $F D I$ & OUTSOURCE \\
\hline \multirow[t]{3}{*}{1} & $R \& D$ & 0.04 & $0.13 * *$ & 0.05 \\
\hline & PROD_INNOV & $2.5^{*}$ & 2.4 & $3.6 *$ \\
\hline & PATENT & $0.10 * *$ & $0.26 * * *$ & $0.11 * *$ \\
\hline \multirow[t]{3}{*}{2} & $R \& D$ & $0.10 * *$ & $0.20 * * *$ & 0.04 \\
\hline & PROD_INNOV & 0.2 & 2.0 & $3.7^{*}$ \\
\hline & PATENT & $0.10 * *$ & $0.27 * * *$ & 0.08 \\
\hline \multirow[t]{3}{*}{3} & $R \& D$ & 0.04 & $0.10 * *$ & $0.14 * *$ \\
\hline & PROD_INNOV & 1.2 & 2.4 & $4.7^{*}$ \\
\hline & PATENT & $0.09 * * *$ & $0.26 * * *$ & 0.06 \\
\hline \multirow[t]{3}{*}{4} & $R \& D$ & 0.05 & $0.20 * * *$ & $0.09 *$ \\
\hline & PROD_INNOV & $3.5^{*}$ & $6.1^{*}$ & $4.3^{*}$ \\
\hline & PATENT & $0.10 * * *$ & $0.25 * * *$ & 0.08 \\
\hline \multirow[t]{3}{*}{5} & $R \& D$ & $0.06 *$ & $0.15^{* * *}$ & $0.11^{* *}$ \\
\hline & PROD_INNOV & 2.8 & 2.7 & $7.6 * *$ \\
\hline & PATENT & $0.10 * *$ & $0.24 * * *$ & $0.10 *$ \\
\hline \multirow[t]{3}{*}{6} & $R \& D$ & 0.04 & 0.09* & $0.10 * *$ \\
\hline & PROD_INNOV & $2.2^{*}$ & 1.2 & 0.8 \\
\hline & PATENT & $0.09 * *$ & $0.25^{* * *}$ & 0.06 \\
\hline \multirow[t]{3}{*}{7} & $R \& D$ & -0.02 & $0.25 * * *$ & 0.03 \\
\hline & PROD_INNOV & $4.9 * *$ & 5.4 & $5.6 * *$ \\
\hline & PATENT & $0.10 * *$ & $0.27 * * *$ & $0.12 * *$ \\
\hline \multirow[t]{3}{*}{8} & $R \& D$ & 0.01 & $0.14^{* *}$ & 0.09 \\
\hline & PROD_INNOV & 1.9 & 0.8 & $6.6 * *$ \\
\hline & PATENT & $0.06 *$ & $0.19 * *$ & $0.12^{* *}$ \\
\hline \multirow[t]{3}{*}{9} & $R \& D$ & $0.10 * *$ & 0.09* & $0.19 * * *$ \\
\hline & PROD_INNOV & 2.0 & -0.5 & -2.9 \\
\hline & PATENT & $0.10 * * *$ & $0.26 * * *$ & $0.10 *$ \\
\hline \multirow[t]{3}{*}{10} & $R \& D$ & 0.04 & $0.16 * *$ & 0.05 \\
\hline & PROD_INNOV & $3.9 *$ & $5.9 *$ & $6.6 * *$ \\
\hline & PATENT & $0.10 * *$ & $0.25 * * *$ & $0.12 * *$ \\
\hline \multirow[t]{3}{*}{11} & $R \& D$ & 0.05 & $0.11^{*}$ & $0.12 * *$ \\
\hline & PROD_INNOV & -1.4 & 1.4 & $6.5^{* *}$ \\
\hline & PATENT & $0.08^{* *}$ & $0.22 * * *$ & $0.10 *$ \\
\hline \multirow[t]{3}{*}{12} & $R \& D$ & $0.09 * *$ & $0.11^{* *}$ & $0.14 * *$ \\
\hline & PROD_INNOV & $4.6 * *$ & 0.1 & 1.2 \\
\hline & PATENT & $0.10 * * *$ & $0.28 * * *$ & 0.08 \\
\hline \multirow[t]{3}{*}{ AVERAGE } & $R \& D$ & 0.05 & 0.15 & 0.09 \\
\hline & PROD_INNOV & 2.54 & 2.42 & 4.08 \\
\hline & PATENT & 0.09 & 0.25 & 0.08 \\
\hline
\end{tabular}

Note: matching procedure is similar to Table 3. Specifications 1-3 use forced (exact) matching on the transition indicator categories, while specifications 4-12 do not apply exact matching. Specifications 4-6 use nearest neighbour matching $(n=5)$. Specifications 1 and 7-9 use Epanechnikov kernels for matching treated and controls. Specifications 2 and 10-12 use one-to-one matching with no replacements. Specification 1,2,4,7, and 10 use the full set of covariates, where specifications 4,7 and 10 also include country dummies. Specifications 5,8 and 11 also apply the full set of covariates but without country specific information. The analyses from 3,6,9 and 12 are based on a minimum set of covariates, where in specification 3 firms are matched on SIZE, AGE and industry dummies before exact matching on transition group. Specifications 6,9 and 12 match on SIZE, AGE, industry and country dummies. 